\title{
Additional Flavonoids from Lonchocarpus yucatanensis and L. xuul
}

\author{
Rocío Borges-Argáez, ${ }^{a, b}$, Maria Esther Poot Díaz, ${ }^{a}$,Peter G. Waterman ${ }^{b}$ \\ and Luis M. Peña-Rodríguez, ${ }^{*, a}$ \\ ${ }^{a}$ Unidad de Biotecnología, Centro de Investigación Científica de Yucatán, A.C., Calle 43 No. 130 \\ Colonia Chuburná de Hidalgo, Mérida 97200, Yucatán, Mexico \\ ${ }^{b}$ Centre for Phytochemistry and Pharmacology, Southern Cross University, PO Box 157, \\ Lismore, NSW 2480, Australia
}

\begin{abstract}
Duas novas flavanonas naturais, 5-hidroxi-6,7-(2",2"-dimetilcromeno)flavanone (1) e 5-metoxi3-hidroxi-6,7-(2",2"-dimetilcromeno)flavanone (2), foram isoladas dos extratos das raízes de $L$. yucatanensis e L. xuul, respectivamente. Adicionalmente, quatro novos metabólitos, os flavanóides glicosídicos quercetina-3-ramnoglucosídeo e caempferol-3-ramnoglucosídeo, juntamente com 4hidroxi-N-metil-prolina, e o éster metílico do ácido p-cumárico, foram isolados pela primeira vez das folhas de L. xuul. Os metabólitos foram identificados usando os dados espectroscópicos obtidos e pela comparação desses com aqueles encontrados na literatura.
\end{abstract}

Two new natural flavanones, 5-hydroxy-6,7-(2",2"-dimethylchromene)flavanone (1) and 5methoxy-3-hydroxy-6,7-(2",2"-dimethylchromene)flavanone (2), were isolated from the root extracts of L. yucatanensis and L. xuul, respectively. Additionally, four known metabolites, the glycosidic flavonoids quercetin-3-rhamnoglucoside and kaempferol-3-rhamnoglucoside, together with 4hydroxy-N-methyl-proline, and $p$-coumaric acid methyl ester, were isolated for the first time from the leaves of $L$. xuul. The various metabolites were identified on the basis of their spectroscopic data and by comparison with those reported in the literature.

Keywords: Lonchocarpus xuul, Lonchocarpus yucatanensis, Leguminosae, Flavanone, Nmethyl proline, p-coumaric methyl ester

\section{Introduction}

Extensive phytochemical studies on the genus Lonchocarpus have led to the identification of numerous flavonoids, in addition to other metabolites such as alkaloids, aminoacids, peptides, triterpenes, sterols, stilbenes and dibenzoylmethane derivatives. ${ }^{1}$ Recently, we reported a number of flavonoids, several of them novel, from Lonchocarpus xuul Lundell and

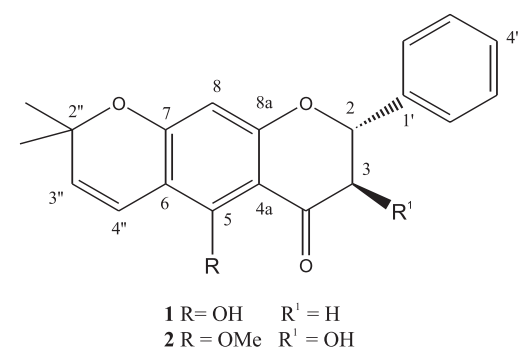

*e-mail: 1manuel@cicy.mx
Lonchocarpus yucatanensis Pittier, ${ }^{2,3}$ two endemic trees growing in the Yucatan Peninsula, where they are both used for building construction and for honey production. ${ }^{4,5}$ As part of our continuing phytochemical investigation of these plants, we wish to report the isolation of additional metabolites from both species.

\section{Results and Discussion}

The hexane fraction of the methanol extract of the root of L. yucatanensis was subjected to successive purifications using VLC, Sephadex LH-20, and preparative TLC (see Experimental) to yield metabolite $\mathbf{1}$ as a pale yellow oil. The IR spectral data of $\mathbf{1}$ suggested the presence of an aromatic ring $\left(1542,1446 \mathrm{~cm}^{-1}\right)$, as well as a conjugated carbonyl function $\left(1631 \mathrm{~cm}^{-1}\right)$ and a hydroxyl group $\left(3446 \mathrm{~cm}^{-1}\right)$.

The ${ }^{1} \mathrm{H}$ NMR of 1 showed a low-field signal ( $\delta$ 12.28), typical of a hydrogen-bonded phenol proton, together with an ABX system $(\delta 5.41,3.08,2.83)$, typical of the axial 
$\mathrm{H}-2$ and the $\mathrm{H}-3$ protons of a flavanone, a $1 \mathrm{H}$ singlet for a single A-ring proton $(\delta 5.90)$, and a multiplet $(\delta 7.45)$ due to the five protons of a monosubstituted B-ring. These signals, and that of a carbonyl carbon resonance at $\delta 196.0$ in the ${ }^{13} \mathrm{C}$ NMR spectrum of $\mathbf{1}$, suggested a 5-hydroxylated flavanone nucleus. ${ }^{6}$ Additional signals in the ${ }^{1} \mathrm{H}$ NMR spectrum included two $\mathrm{cis}$-coupled olefinic protons $(\delta 5.51$ and 6.63) and two methyl group singlets ( $\delta 1.45$ and 1.46), typical of a 2,2-dimethylpyran system. Placement of the 2,2-dimethylpyran-ring system at C-6 and C-7 of the flavanone was rationalized from correlations observed in the HMBC experiment between the hydroxyl group proton and C-5, C-4a and C-6, in addition to those between $\mathrm{H}-4$ " and C-5 and C-7 and of H-8 with C-6, C-7, C-8a and C-4a. On the basis of this data, metabolite $\mathbf{1}$ was identified as 5hydroxy-6,7-(2",2"-dimethylchromene)flavanone, a hydroxy chromenoflavanone previously reported as the DDQ-catalyzed cyclization product of 5,7-dihydroxy-6prenyl-flavanone. ${ }^{7}$ This, however, is the first report of 1 occurring naturally.

Similarly, successive chromatographic purifications of the methanol extract of the root of $L$. xuul, resulted in the isolation of metabolite $\mathbf{2}$. As in the case of $\mathbf{1}$, the IR spectrum of $\mathbf{2}$ displayed absorption bands for hydroxyl $\left(3436 \mathrm{~cm}^{-1}\right)$ and conjugated carbonyl $\left(1671 \mathrm{~cm}^{-1}\right)$ functional groups.

The ${ }^{1} \mathrm{H}$ NMR of $\mathbf{2}$ was very similar to that of $\mathbf{1}$, showing the characteristic five-proton multiplet of a monosubstituted B-ring and the corresponding signals for a 2,2dimethylpyran system. The main difference observed in the ${ }^{1} \mathrm{H}$ NMR of $\mathbf{2}$ was the presence of an AB spin system at $\delta 5.03$ and $4.46(J=12.0 \mathrm{~Hz})$ that could be assigned to the trans diaxial $\mathrm{H}-2$ and $\mathrm{H}-3$ protons of a 3-hydroxyflavanone. This was confirmed by the presence of a carbonyl carbon signal at $\delta 190.4(\mathrm{C}=\mathrm{O})$ and two oxygenated methine signals at $\delta 83.3(\mathrm{C}-2)$ and $\delta 72.8(\mathrm{C}-3)$ in the ${ }^{13} \mathrm{C}$ NMR spectrum of 2. Furthermore, the presence of a methoxyl group in the structure of $\mathbf{2}$ was indicated by the substitution of the hydrogen-bonded proton signal in the ${ }^{1} \mathrm{H}$ NMR of $\mathbf{1}$ for a three-proton singlet at $\delta 3.84$, with a corresponding signal at $\delta 55.9$ in the ${ }^{13} \mathrm{C}$ NMR spectrum of 2 . The placement of the pyran ring in the $6 / 7$ positions was, as in 1, confirmed by correlations observed in the HMBC experiment; namely, the correlations observed between the methoxyl-methyl group protons and $\mathrm{C}-5$, together with those between H-4" and C-5, C-2" and C-7. Similarly, the location of the hydroxyl group at C-3 was confirmed by HMBC correlations between $\mathrm{H}-3$ and C-2, C-4 and C-1' and between $\mathrm{H}-2$ and $\mathrm{C}-4$. This data, and the fact that the $\alpha$-orientation of the $\mathrm{C}-3$ phenyl group is usually dominant in flavanones, ${ }^{8}$ allowed placement of the C-3 hydroxyl group in the $\beta$-orientation and the identification of $\mathbf{2}$ as 5 m e th ox y - 3-hydrox y - 6, 7 - ( 2 ", 2 " dimethylchromene)flavanone, a metabolite which appears to be a new natural product.

Finally, purification of the methanol extract of the leaves of $L$. xuul yielded four known metabolites identified as quercetin-3-O-rhamnoglucoside, kaempferol-3-Orhamnoglucoside, 4-hydroxy-N-methylproline, and $p$ coumaric acid methyl ester by comparing their spectroscopic data (IR, UV, MS, ${ }^{1} \mathrm{H}$ and ${ }^{13} \mathrm{C}$ NMR) to those reported in the literature. Both flavonol glycosides have been previously reported from many plant species; ${ }^{9}$ similarly, 4-hydroxy-N-methylproline has been previously isolated from Copaifera spp (Leguminosae), ${ }^{10}$ Melaleuca lanceolata (Myrtaceae) ${ }^{11}$ and the red alga Chondria coerulescens,${ }^{12}$ while $p$-coumaric acid methyl ester has been reported from long English cucumber leaves. ${ }^{13}$ This however, is their first report as metabolites from $L$. xuul.

\section{Experimental}

\section{General}

Melting points (uncorrected) were determined on a Fluka 70/20 series II Holster C70G apparatus. UV spectra were recorded on a Beckman DU-65 spectrophotometer using $\mathrm{MeOH}$ or $\mathrm{CHCl}_{3}$ (HPLC grade) as solvent. NMR spectra (both 1D and 2D) were obtained on an AVANCE DRX500 Bruker spectrometer, using the residual solvent peaks as the reference signal. Mass spectral analyses were determined on an Agilent 1100 series LC/MSD; using electrospray (ESI) and atmospheric pressure chemical ionization (APCI) as the ionization techniques. HRFABMS (+) was obtained on a JEOL JMS-SX102A apparatus. Vaccum-liquid chromatography (VLC) was carried out using Merck Si gel $60 \mathrm{H}$, and column chromatography using Merck Si gel 60 (70-230 mesh) or Sephadex LH-20 (Sigma, size 25-100). Flash chromatography was performed using Merck Si gel 60 (230-400 mesh) and preparative TLC was run using glass-coated silica gel F254 $(0.20 \mathrm{~mm}$ thick) plates. Analytical TLC was carried out on precoated aluminum plates using Merck Si gel F254; the plates were visualized under UV light ( $\lambda 254$ and $366 \mathrm{~nm}$ ) and by spraying with phosphomolybdic acid reagent, followed by gentle heating.

\section{Plant material}

The species investigated were collected in June 1997 from trees growing at the $9 \mathrm{~km}$ post of the Yokdzonot-Pisté highway $($ L.xuul $)$ and at the $7 \mathrm{~km}$ post of the Mérida-Holcá 
highway (L. yucatanensis), in Yucatan, México. Voucher specimens were deposited in the Herbarium of the Unidad de Recursos Naturales of Centro de Investigación Científica de Yucatán (CICY) under the collection numbers 1089 ( $L$. xuul) and 1103 (L. yucatanensis).

\section{Extraction and isolation}

For a detailed description on the amount of plant material used, as well as on the initial extraction and fractionation procedures, see Borges-Argáez et al., 2002 and 2000. ${ }^{2,3}$ The hexane fraction $(10 \mathrm{~g})$ of the root methanolic extract of L. yucatanensis was subjected to an initial VLC fractionation, eluting with hexane and hexane:EtOAc (gradient elution), to produce seven fractions (F1A-F1G). Fraction F1A (816 mg) was further purified using $\mathrm{CC}$ (hexane/EtOAc, 95:5; hexane/ $\mathrm{CH}_{2} \mathrm{Cl}_{2}$, 90:10) and yielded three fractions (F2A-F2C). Fraction F2B (22 mg) was then purified by prep-TLC (hexane/ EtOAc, 95:5) to produce $4 \mathrm{mg}$ of metabolite $\mathbf{1}$.

A similar purification of the hexane fraction $(13 \mathrm{~g})$ of the methanol extract of the root of L. xuul, using VLC (hexane/acetone gradient elution), afforded 12 fractions (F3A-F3L). Fraction F3E (152 mg) was subjected to flash CC (hexane/EtOAc, 85:15) to produce 13 fractions (F4AF4M). Succesive purifications, CC (Sephadex LH-20; $100 \% \mathrm{MeOH}$ ) and prep-TLC (hexane/acetone, 8:2), of fraction F4M (127 mg) yielded $12 \mathrm{mg}$ of the new metabolite 2 .

The methanol extract $(2.4 \mathrm{~g})$ of the leaves of $L$. $x u u l$ was passed through a Sephadex LH-20 column using methanol as the eluant. One of the fractions (F5B, 161 $\mathrm{mg})$ was further purified using Sephadex $\mathrm{LH}-20\left(\mathrm{CHCl}_{3} /\right.$ $\mathrm{MeOH}$, gradient elution) to produce four new fractions (F6A-F6D). Purification of fraction F6C (42 mg) by CC $\left(\mathrm{CH}_{2} \mathrm{Cl}_{2} / \mathrm{MeOH} / \mathrm{H}_{2} \mathrm{O}, 4.0: 0.5: 0.1\right)$ yielded $9.7 \mathrm{mg}$ of quercetin-3-rhamnoglucoside, obtained as a yellow powder; similar $\mathrm{CC}$ purification $\left(\mathrm{CHCl}_{3}: \mathrm{MeOH}, 9: 1\right.$; $\mathrm{CH}_{2} \mathrm{Cl}_{2}: \mathrm{MeOH}: \mathrm{H}_{2} \mathrm{O}, 4.0: 0.5: 0.1$ ) of fraction F6B (43 mg) led to the isolation of kaempferol-3-rhamnoglucoside $(6 \mathrm{mg})$, also as a yellow powder.

An additional portion $(4.8 \mathrm{~g})$ of the methanolic extract of the leaves of L. xuul was subjected to VLC (EtOAc:MeOH, gradient elution) to give three fractions (F7A-F7C). Fraction F7B (2 g) was purified by flash chromatography $\left(\mathrm{CH}_{2} \mathrm{Cl}_{2}: \mathrm{MeOH}, 8: 2 ; \mathrm{CH}_{2} \mathrm{Cl}_{2}: \mathrm{MeOH}, 7: 3\right)$ to yield $10.9 \mathrm{mg}$ of colorless needles identified as 4hydroxy-N-methylproline.

Finally, VLC purification (hexane:EtOAc, gradient elution) of the hexane fraction ( $10 \mathrm{~g}$ ) from the methanolic leaf extract of L. xuul afforded nine major fractions (F8A-
F8H). Fraction F8F (738 mg) was passed through a Sephadex LH-20 column ( $\mathrm{CHCl}_{3}: \mathrm{MeOH}$, gradient elution) and further purified by succesive $\mathrm{CC}$ (hexane:EtOAc, 8:2) and prep-TLC (Benzene:acetone, 8:2) to produce $2.8 \mathrm{mg}$ of pure $p$-coumaric-methylester as brownish needles.

5-hydroxy-6,7-(2",2"-dimethylchromene)flavanone (1). Yellow oil. IR (film) $v_{\text {max }} / \mathrm{cm}^{-1}: 3446(\mathrm{OH}), 2966,1631$ $(\mathrm{C}=\mathrm{O}), 1542$, 1446. UV $(\mathrm{MeOH}) \lambda_{\max } / \mathrm{nm}: 270,292 .{ }^{1} \mathrm{H}$ NMR (500 MHz, $\left.\mathrm{CDCl}_{3}\right): 1.45(3 \mathrm{H}, \mathrm{s}), 1.46(3 \mathrm{H}, \mathrm{s}), 2.83$ (1H, dd, J 17.0, 3.0 Hz, H-3eq), 3.08 (1H, dd, J 17.0, 13.0 Hz, H-3ax), 5.41 (1H, dd, J 13.0, 3.0 Hz, H-2), 5.51 (1H, d, J 10.0 Hz, H-3"), 5.90 (1H, s, H-8), 6.63 (1H, d, J $10.0 \mathrm{~Hz}$, H-4”), 7.45 (5H, m, H-2'-H6'), 12.28 (1H, s, OH). ${ }^{13} \mathrm{C} \mathrm{NMR}$ (150 MHz, $\left.\mathrm{CDCl}_{3}\right)$ : 28.6 (Me-2"), 28.7 (Me-2”), 43.6 (C3), 78.0 (C-2”), 79.4 (C-2), 96.5 (C-8), 105.0 (C-4a/C6), 115.5 (C-4”), 126.3 (C-2', C-6'), 126.5 (C-3”), 129.8 (C3', C-4', C-5'), 138.7 (C-1'), 158.7 (C-5), 162.4 (C-7), 162.6 (C-8a), 196.0 (C-4).

5 - me th o $x y-3-h y d r$ o $x y-6,7-(2$ ", 2 ”dimethylchromene)flavanone(2). Yellow powder. IR (Film) $v_{\max } / \mathrm{cm}^{-1}: 3436(\mathrm{OH}), 1671(\mathrm{C}=\mathrm{O}), 1593,1439 .[\alpha]_{\mathrm{D}}-25.9^{\circ}$ (c $\left.0.0027, \mathrm{CHCl}_{3}\right)$. UV $\left(\mathrm{CHCl}_{3}\right) \lambda_{\text {max }} / \mathrm{nm}: 260,297 .{ }^{1} \mathrm{H}$ NMR (400 MHz, $\left.\mathrm{CDCl}_{3}\right): 1.48$ (3H, s, Me-2"), 1.58 (3H, s, Me-2”), 3.84 (3H, s, OMe-5), 4.46 (1H, d, J 12 Hz, H3), 5.03 (1H, d, J 12 Hz, H2), 5.52 (1H, d, J 10 Hz, H3”), 6.08 (1H, s, H8), 6.55 (1H, d, J10 Hz, H4”), 7.48 (3H, m, H3', H4', H5'), 7.57 (2H, m, H2'/H6'). ${ }^{13} \mathrm{C}$ NMR (125 MHz, $\left.\mathrm{CDCl}_{3}\right): 27.8$ (Me-2”), 28.1 (Me-2"), $55.9\left(\mathrm{OCH}_{3}\right), 72.8$ (C3), 77.2 (C2"), 83.3 (C2), 92.0 (C8), 102.9 (C4a), 105.2 (C6), 115.8 (C4”), 126.6 (C3”), 127.5 (C2',C6'), 128.7 (C3',C5'), 129.2 (C4'), 136.5 (C1'), 155.6 (C7), 161.3 (C5), 163.6 (C8a), 190.4 (C4). HRFABMS(+): $m / z$ (rel. int.): $353.1414[\mathrm{M}+\mathrm{H}]^{+}$(7.9) (calc. for $\mathrm{C}_{21} \mathrm{H}_{21} \mathrm{O}_{5}: 353.1389$ ).

\section{Acknowledgements}

The authors wish to thank Paulino Simá-Polanco, Unidad de Recursos Naturales CICY, for originally identifying and collecting the plant material. Ms Gilda Erosa and Prof. Olov Sterner, of the Department of Bioorganic Chemistry, University of Lund, for providing the HRFABMS analysis, and Ms Fabiola Escalante and Dr. Sergio Peraza for the UV and optical rotation determinations.

\section{References}

1. Hegnauer, R.; Hegnauer, M.; Chemotaxonomie der Pflanzen, vol. XIb-2, Birkhauser Verlag: Basle, 2001, pp. 194-203. 
2. Borges-Argáez, R.; Peña-Rodríguez, L.M.; Waterman, P.G.; Phytochemistry 2002, 60, 533.

3. Borges-Argáez, R.; Peña-Rodríguez, L.M.; Waterman, P.G.; Phytochemistry 2000, 54, 611.

4. Mendieta, R.M.; Del Amo, R.S.; Plantas Medicinales del Estado de Yucatán, CECSA: Xalapa, Veracruz, 1981.

5. Durán, R.; Trejo-Torres, J.C.; Ibarra-Manríquez, G.; Harv. Pap. Bot. 1998, 3, 265.

6. Mabry, T.J.; Markham, K.R.; Thomas, M.B.; The Systematic Identification of Flavonoids, Springer-Verlag: Berlin,1970.

7. Manchanda, V.P.; Batta, A.K.; Khanna, P.L.; Khanna, R.L.; Curr. Sci. 1976, 45, 322.

8. Rahman, M.M.; Gray, A.I.; Phytochemistry 2002, 59, 73.
9. Harborne, J.B.; Baxter, J.; Handbook to Flavonoids Pigments, John Wiley \& Sons: New York, 1999.

10. Figliuolo, R.; Naylor, S.; Wang, J.; Langenheim, J.; Phytochemistry 1987, 26, 3255.

11. Jones, G. ; Naidu, B. ; Paleg, L. ; Tiekink, E.; Snow, M.; Phytochemistry 1987, 26, 3343.

12. Sciuto, S.; Chillemi, R.; Piattelli, M.; Impellizzeri G.; Phytochemistry 1983, 22, 2311.

13. Daayf, F.; Bel-Rhlid, R.; Belanger, R.; J. Chem. Ecol. 1997, $23,1517$.

Received: November 12, 2004 Published on the web: August 24, 2005 